\title{
Bermudagrass Freezing Tolerance Associated with Abscisic Acid Metabolism and Dehydrin Expression during Cold Acclimation
}

\author{
Xunzhong Zhang', Kehua Wang, and Erik H. Ervin \\ Department of Crop and Soil Environmental Sciences, Virginia Polytechnic Institute and State \\ University, 351A Smyth Hall, Blacksburg, VA 24061-0404
}

\begin{abstract}
AdDitional INDEX wORDs. Cynodon dactylon, electrolyte leakage, hormone, low temperature, protein
Abstract. Recent advances in bermudagrass [Cynodon dactylon (L.) Pers. var. dactylon] breeding and cultural management practices have enabled its use as a sports surface in U.S. Department of Agriculture cold hardiness zones 5 and 6. Use of these more cold-hardy bermudagrass cultivars further into transition- and cool-season zones increases the probability of freezing injury and increases the need for an improved understanding of physiological responses to chilling and freezing temperatures. Abscisic acid (ABA) has been shown to increase during cold acclimation (CA) and play a role in dehydration tolerance. This study investigated changes in ABA metabolism and dehydrin expression during CA and their association with freezing tolerance in four bermudagrass cultivars. Two cold-tolerant ('Patriot' and 'Riviera') and two relatively cold-sensitive ('Tifway' and 'Princess') cultivars were either subjected to $\mathrm{CA}$ at $8^{\circ} \mathrm{C}$ day $/ 4^{\circ} \mathrm{C}$ night with a light intensity of $250 \mu \mathrm{mol} \cdot \mathrm{m}^{-2} \cdot \mathrm{s}^{-1}$ over a 10 -h photoperiod for 21 days or maintained at $28{ }^{\circ} \mathrm{C}$ day $/ 24^{\circ} \mathrm{C}$ night over a 12-h photoperiod. In a separate study, exogenous $\mathrm{ABA}$ at $0,50,100$, and $150 \mu \mathrm{M}$ was applied to 'Patriot' bermudagrass without $\mathrm{CA}$. ABA content in leaf and stolon tissues increased substantially during the first week of CA and remained relatively stable thereafter. 'Patriot' and 'Riviera' had greater ABA content and less stolon electrolyte leakage (EL) relative to 'Tifway' and 'Princess'. Expression of a $25 \mathrm{kDa}$ dehydrin protein increased during CA in all four cultivars. A significant correlation was found between ABA content and freezing tolerance. Exogenously applying ABA to 'Patriot' at 50, 100, and $150 \mu \mathrm{M}$ significantly increased endogenous ABA content and the $25 \mathrm{kDa}$ dehydrin expression and reduced stolon EL. The results suggest that alteration of ABA metabolism during $\mathrm{CA}$ is closely associated with freezing tolerance. Selection and use of cultivars with substantial accumulation of $\mathrm{ABA}$ and certain dehydrins during $\mathrm{CA}$ or in response to exogenous $\mathrm{ABA}$ could improve bermudagrass persistence in transition zone climates.
\end{abstract}

Common bermudagrass is widely distributed throughout the world between latitudes $45^{\circ} \mathrm{N}$ and $45^{\circ} \mathrm{S}$ (Anderson et al., 1993; Harlan and de Wet, 1969), and both common and triploid hybrid [Cynodon $\times$ magennisii Hurcombe $(=C$. dactylon $\times C$. transvaalensis Burtt-Davy)] are used in turf systems (McCarty and Miller, 2002). Bermudagrasses grown in the transition zone of the United States are subject to freeze damage (Anderson et al., 2003; Fry, 1990; Taliaferro et al., 2004) and periodic severe winterkill (Anderson et al., 1997; Hiscock, 1996; Munshaw, 2004; Zhang et al., 2006).

Bermudagrasses undergo cold acclimation (CA), which is induced by a combination of reduced photoperiod and temperatures of less than $10{ }^{\circ} \mathrm{C}$ in the autumn. Cold-acclimated cultivars can develop metabolic defenses rapidly to cope with freezing stress (Zhang et al., 2006). Increases in certain sugars or amino acids, synthesis of novel proteins, and increases in the degree of unsaturation of membrane lipid fatty acids, antioxidant capacity, and certain hormones are some of the most important metabolic defenses against freezing stress (Cyril et al., 2002; Hughes and Dunn, 1996; Kalberer et al., 2006; Karpinski et al., 2002; Lee and Chen, 1993; Munshaw et al., 2006; Perras and Sarhan, 1989; Zhang et al., 2006; Zhang and Ervin, 2008).

Abscisic acid (ABA) plays an important role in low temperature response and is correlated with enhanced freezing tolerance in some plant species (Lee and Chen, 1993). It has

Received for publication 20 Mar. 2008. Accepted for publication 27 May 2008 ${ }^{1}$ Corresponding author. E-mail: xuzhang@vt.edu. been reported that endogenous ABA increases during cold acclimation and that application of ABA may induce freezing tolerance in several plant species (Lee and Chen, 1993). A mutant of arabidopsis [Arabidopsis thaliana (L.) Heynh.] deficient in ABA was unable to cold-acclimate unless treated with exogenous ABA (Heino et al., 1990). Exogenous ABA has been shown to induce dehydrin gene expression (Han and Kermode, 1996).

Dehydrin proteins (late embryogenesis abundant D11 family) are members of a family of proteins that range in size from 9 to $200 \mathrm{kDa}$. They have been shown to be expressed after plant exposure to environmental stimuli with a dehydrative component, including low temperature, drought, salinity, and developmental stages such as seed and pollen maturation (Close, 1997). Dehydrins have been postulated to stabilize cell structures against dehydration (Close, 1997; Danyluk et al., 1998). In several plant species, dehydrins have been shown to possess in vitro cryoprotective activity and in vivo antifreeze activity (Wisniewski et al., 1999). Dehydrins have also been suggested to function as possible osmoregulators (Nylander et al., 2001) or as radical scavengers (Hara et al., 2003). Several researchers have reported that dehydrin accumulation is correlated with freezing tolerance in some plant species (Marian et al., 2003; Zhu et al., 2000). Danyluk et al. (1998) noted that the WCOR410 dehydrin protein accumulated near the plasma membrane during $\mathrm{CA}$ of wheat (Triticum aestivum L.) and suggested that this accumulation protected integrity of the plasma membrane when plants were subjected to stress. Patton 
et al. (2007) found that dehydrin polypeptides of 23 and $25 \mathrm{kDa}$ increased during CA and that the $23 \mathrm{kDa}$ dehydrin polypeptide was associated with freezing tolerance of zoysiagrass (Zoysia Willd.).

The electrolyte leakage technique is commonly used to assess the level of cell injury caused by low temperatures and to test the relative freezing tolerance of turfgrasses (Anderson et al., 1988, 2002; Cardona et al., 1997; Fry et al., 1991; Miller and Dickens, 1996; Shashikumar and Nus, 1993; Zhang et al., 2006). The concept of lethal temperature for $50 \%$ loss of electrolytes (LT50) has been used as a measure of cold hardiness and is defined as the predicted test temperature resulting in $50 \%$ or greater loss of total electrolytes (Shashikumar and Nus, 1993). When interpreting these results, it has been assumed that an electrolyte leakage (EL) of $50 \%$ or more is lethal (Fry et al., 1993). Predicted LT50 based on EL and glasshouse regrowth evaluations have been reported to be in close agreement when bermudagrass was tested (Anderson et al., 1988; Miller and Dickens, 1996; Zhang et al., 2006).

Bermudagrass cultivars vary largely in freezing tolerance (Anderson et al., 2003; Taliaferro et al., 2004). 'Patriot' $(2 n=$ $4 x=36$ chromosomes) and 'Tifway' $(2 n=3 x=27$ chromosomes) are vegetatively propagated hybrid cultivars, whereas 'Riviera' and 'Princess' are common seeded cultivars $(2 n=4 x=$ 36 chromosomes). 'Patriot' and 'Riviera' were top performers among all cultivars in the 2003 to 2006 National Turfgrass Evaluation Program (NTEP) bermudagrass test and have excellent cold tolerance and high turf quality ratings (NTEP, 2008; Taliaferro et al., 2004). 'Tifway' and 'Princess' are widely used cultivars with highly rated visual quality but a medium level of cold tolerance. Enhancement of cultivar freezing tolerance as a means of reducing risk of winterkill has been a major goal of many bermudagrass improvement programs (Anderson et al., 2003). However, there are few reports on the physiological mechanisms of cultivar variation in freezing tolerance. Investigations concerning the physiological bases of cultivar differences in freezing tolerance would provide valuable selection information for turfgrass breeders and practitioners, especially in the transition zone. The objectives of this study were: 1) to examine changes in the levels of endogenous $\mathrm{ABA}$ and dehydrin proteins during $\mathrm{CA}$ and to investigate relationships of $\mathrm{ABA}$ and dehydrins with freezing tolerance; and 2) to examine if exogenous ABA affects endogenous ABA level and dehydrin expression associated with freezing tolerance in bermudagrass.

\section{Materials and Methods}

Turfgrass CUlTuRe, COLD ACCLIMATION, AND ABSCISIC ACID TREATMENT. Four bermudagrass cultivars, 'Patriot' and 'Riviera' (cold-tolerant) and 'Tifway' and 'Princess' (relatively cold-sensitive), were used for this study. Mature bermudagrass plugs ( $10 \mathrm{~cm}$ diameter $\times 5 \mathrm{~cm}$ deep) were taken from field plots at the Virginia Tech Turfgrass Research Center, Blacksburg, VA, on 2 Aug. 2007 and grown in pots $(12.5 \mathrm{~cm}$ diameter $\times 12.0$ $\mathrm{cm}$ deep) filled with medium-textured sand and having three holes at the bottom to allow drainage. The grass was grown in a temperature-controlled glasshouse at $25{ }^{\circ} \mathrm{C}$ day/23 ${ }^{\circ} \mathrm{C}$ night with natural sunlight plus artificial light (Ruud Lighting, Racine, WI) [average $\approx 380 \mu \mathrm{mol} \cdot \mathrm{m}^{-2} \cdot \mathrm{s}^{-1}$ photosynthetically active radiation $(P A R)$, a $12-\mathrm{h}$ photoperiod]. Nitrogen was applied at $45 \mathrm{~kg} \cdot \mathrm{ha}^{-1}$ with a $20 \mathrm{~N}-8.8 \mathrm{P}-16.6 \mathrm{~K}$ soluble fertilizer containing micronutrients $2 \mathrm{~d}$ after the plugs were transplanted and every 4 weeks thereafter.

Twelve weeks after transplanting, the four cultivars were subjected to two treatments: CA and noncold acclimation (NA). Four pots from each cultivar were transferred to a growth chamber and subjected to $\mathrm{CA}$ at $8 / 4{ }^{\circ} \mathrm{C}$ (day/night) with a $P A R$ intensity of $250 \mu \mathrm{mol} \cdot \mathrm{m}^{-2} \cdot \mathrm{s}^{-1}$ over a 10 -h photoperiod for a period of $21 \mathrm{~d}$. For NA, one pot from each cultivar was maintained at a normal temperature $\left(28{ }^{\circ} \mathrm{C}\right.$ day $/ 24{ }^{\circ} \mathrm{C}$ night $)$ in another growth chamber with the same $P A R$ intensity and 12$\mathrm{h}$ photoperiod.

To investigate effects of exogenous ABA application, ABA solutions at $0,50,100$, and $150 \mu \mathrm{M}$, containing $0.01 \%(\mathrm{v} / \mathrm{v})$ Tween 20 (Sigma, St. Louis), were sprayed uniformly to the canopy of 'Patriot' bermudagrass at a dosage of $10 \mathrm{~mL}$ per pot on 23 Oct. and again on 24 Oct. 2007. The treated grass was transferred to a growth chamber and maintained at a normal temperature $\left(28{ }^{\circ} \mathrm{C}\right.$ day $/ 24{ }^{\circ} \mathrm{C}$ night $)$ with the same $P A R$ intensity as described previously. Only one cultivar was used in the exogenous ABA treatment trial because of space limitations in the growth chamber. 'Patriot' was selected because it is one of the most important cultivars used in Virginia and more genetically uniform relative to the seeded cultivars. The grass was mowed to $1.25 \mathrm{~cm}$ weekly until CA was initiated or ABA treatment. The grass plugs were watered once per week but not fertilized during the 3 -week period in the growth chambers.

SAMPle Collection. At $0,7,14$, and $21 \mathrm{~d}$ after CA initiation, leaf and stolon samples were collected for analysis of EL, ABA content, and dehydrin expression. The EL was measured immediately after sampling and the samples for ABA and dehydrin analysis were immediately frozen with liquid $\mathrm{N}$ and stored at $-80{ }^{\circ} \mathrm{C}$.

ABsCisic ACID ASSAY. Leaf or stolon tissue (100 mg) was ground to a powder using a mortar and a pestle in liquid nitrogen. The sample was extracted in $2 \mathrm{~mL}$ methanol containing $0.01 \%$ butylated hydroxytoluene overnight. The sample was centrifuged at $2000 g_{n}$ for $15 \mathrm{~min}$ and the supernatant was collected and dried in a stream of air.

The ABA sample was purified using a $\mathrm{C}_{18}$ Sep-Pack column (Waters, Milford, MA). The $\mathrm{C}_{18}$ Sep-Pack column was flushed

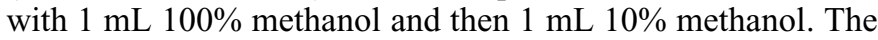
ABA sample was dissolved in 10\% methanol and loaded into the column. The container was washed with $1 \mathrm{~mL} 10 \%$ methanol two times and the column flushed. The ABA was eluted with $1 \mathrm{~mL} 80 \%$ methanol and dried in a stream of air. The sample was dissolved in $100 \mu \mathrm{L}$ methanol and diluted with tris-buffered saline (TBS) buffer.

Indirect enzyme-linked immunosorbent assay was used for ABA estimation according to Walker-Simmons et al. (2000) with some modifications. Briefly, wells of a 96-unit plate were coated with $200 \mu \mathrm{L}$ per well ABA-C4-bovine serum albumin (BSA) conjugate (1:250 dilution) and incubated overnight at $4{ }^{\circ} \mathrm{C}$ in the dark. The plate was emptied and washed three times with TBS buffer containing $0.05 \%$ Tween $20(\mathrm{v} / \mathrm{v})$ and $0.1 \%$ BSA (w/v). The reaction was blocked with $200 \mu \mathrm{L}$ TBS containing $0.05 \%$ Tween 20 and $1 \%$ BSA $\left(25{ }^{\circ} \mathrm{C}\right.$; $\left.15 \mathrm{~min}\right)$. After the plate was washed three times with TBS containing $0.05 \%$ Tween $20(\mathrm{v} / \mathrm{v})$ and $0.1 \%$ BSA (w/v), $200 \mu \mathrm{L}$ anti-ABA monoclonal antibody (ABA antibody; Agdia, Elkhart, IN) + standard or ABA antibody + sample was added to each well. ABA antibody + standard and ABA antibody + sample 
mixtures were made by incubating the mixtures (1:1 ratio) overnight at $4{ }^{\circ} \mathrm{C}$ in the dark. The plate was incubated $2.5 \mathrm{~h}$ at $25^{\circ} \mathrm{C}$ in the dark, emptied, and washed three times.

To each well, $200 \mu \mathrm{L}$ antimouse IgG alkaline phosphatase (1:1000 dilution) solution (Sigma) was added, and the plate was incubated $2 \mathrm{~h}$ at $25^{\circ} \mathrm{C}$ in the dark. After three washes with TBS containing $0.05 \%$ Tween $20(\mathrm{v} / \mathrm{v})$ and $0.1 \% \mathrm{BSA}(\mathrm{w} / \mathrm{v}), 200 \mu \mathrm{L}$ $p$-nitrophenyl phosphate disodium salt $\left(1 \mathrm{mg} \cdot \mathrm{mL}^{-1}\right.$ in $0.05 \mathrm{M}$ $\mathrm{NaHCO}_{3}, \mathrm{pH}$ 9.6) were added to each well and incubated in the dark for $\approx 1 \mathrm{~h}$. The color reaction was determined by measuring absorbance at $405 \mathrm{~nm}$ with an enzyme immunoassay microplate reader (Opsys MR; Thermo Labsystems, Chantilly, VA). The ABA concentration was calculated on the basis of a prepared standard curve and expressed as $\mathrm{ng} \cdot \mathrm{g}^{-1}$ dry weight.

DEHYDRIN EXPRESSION ANALYSIS. Stolon tissues were used for dehydrin expression analysis because they are closely associated with winter survival of bermudagrass and also used in evaluating freezing tolerance based on stolon EL in this study. Stolons $(250 \mathrm{mg})$ were grounded using liquid nitrogen and transferred to 2-mL mirocentrifuge tubes. Then the powder was mixed with $1.5 \mathrm{~mL}$ precooled extraction buffer [50 mM Tris$\mathrm{HCl} \mathrm{pH} \mathrm{6.8,} 1 \mathrm{~mm}$ ethylenediaminetetraacetic acid, 1\% SDS, and $0.5 \%$ polyvinylpyrrolidone, plus the protease inhibitor phenylmethylsulfonyl fluoride (1 mm; Sigma)]. The mixture was kept on ice for 5 min before centrifugation. The extracts were centrifuged at $16,000 g_{\mathrm{n}}$ at $4{ }^{\circ} \mathrm{C}$ for $15 \mathrm{~min}$, and the supernatant was transferred to new microcentrifuge tubes and kept on ice. Next, $20 \mu \mathrm{L}$ of fourfold diluted aliquot of extract was used for a protein concentration assay using bicinchoninic acid reagent (Sigma). The reaction mixture was read at $562 \mathrm{~nm}$ after 30-min incubation at $37^{\circ} \mathrm{C}$ with BSA as the standard.

An aliquot of $100 \mu \mathrm{L}$ supernatant mixed with $100 \mu \mathrm{L}$ of $2 \times$ SDS buffer $\left[0.125 \mathrm{~mol} \cdot \mathrm{L}^{-1}\right.$ Tris $/ \mathrm{HCl}, \mathrm{pH} 6.8,20 \%(\mathrm{v} / \mathrm{v})$ glycerol, $0.01 \%$ (v/v) bromphenol blue, $200 \mathrm{~mm}$ dithiothreitol, and $4 \%(\mathrm{w} / \mathrm{v})$ SDS] was used for Sodium dodeclysulfate polyacrylamide gel electrophoresis analysis (Laemmli, 1970) after heating in a boiling water bath for $3 \mathrm{~min}$. Each lane was loaded with $50 \mu \mathrm{g}$ protein with the proteins separated in 1.0mm-thick gels (15\% separating gel, 5\% stacking gel) at constant volts of 200 using Bio-Rad Mini-Protean III (BioRad Laboratories, Hercules, CA). The separated proteins was transferred for $1 \mathrm{~h}$ at constant volts of 100 and blotted onto 0.45 $\mu \mathrm{m}$ nitrocellulose membrane (Bio-Rad Laboratories). After blotting, the membrane was blocked with 3\% BSA in TBS (25 mM Tris-HCl, $150 \mathrm{~mm} \mathrm{NaCl}, \mathrm{pH} 7.5$ ) for $1.5 \mathrm{~h}$ at room temperature. After a brief rinse with TBS, the membrane was incubated in TBS with a dehydrin polyclonal antibody raised from rabbit (Assay Designs, Ann Arbor, MI) at a dilution of $1: 250$ for $1.5 \mathrm{~h}$. After that the membrane was rinsed in TBS containing $0.5 \%$ Tween 20 (TBS-T) four times and then placed for $1 \mathrm{~h}$ in a solution of goat antirabbit $\operatorname{IgG}$ (dilution 1:17,500) conjugated to alkaline phosphatase (Sigma). The membrane was rinsed in TBS-T four times and then developed using nitroblue tetrazolium and 5-bromo-4-chloro-3-indolyl phosphate (Sigma). Immunoblotting was conducted for three replications and the representative data are presented here.

Electrolyte leakage. At the end of CA, the soil was washed from the plants and the roots were removed. Turf plugs from acclimated and nonacclimated treatments were then divided into five subsamples. Each subsample was wrapped in a wet paper towel and subjected to a series of freezing temperatures. A freezing chamber was programmed to cool to $-2,-4,-6,-8$, and $-10{ }^{\circ} \mathrm{C}$ with a $2^{\circ}$ decline every $2 \mathrm{~h}$ at which time a subsample was removed for analysis. After thawing overnight at $4{ }^{\circ} \mathrm{C}$, stolons (100 $\mathrm{mg}$ ) from each subsample were rinsed with distilled water and transferred into a $50-\mathrm{mL}$ centrifuge tube and deionized distilled water $(20 \mathrm{~mL})$ was added. The samples were placed in a shaker for $12 \mathrm{~h}$ at $25^{\circ} \mathrm{C}$. After an initial electrical conductivity $\left(\mathrm{EC}_{1}\right)$ reading using a conductivity meter, the samples were autoclaved at $120^{\circ} \mathrm{C}$ for $30 \mathrm{~min}$. After cooling, a second $\mathrm{EC}\left(\mathrm{EC}_{2}\right)$ reading was taken. The EL $(\%)$ is expressed as $\left(\mathrm{EC}_{1} / \mathrm{EC}_{2}\right) \times 100$. The EL was also measured for the samples collected at $0,7,14$, and $21 \mathrm{~d}$ after $\mathrm{CA}$ initiation or ABA treatment.

DETERMINATION OF LETHAL TEMPERATURE FOR 50\% LOSS OF ELECTROLYTES. Freezing tolerance was evaluated based on predicted LT50 from EL measurements in this study. Predicted LT50 and glasshouse regrowth evaluation after freezing treatment of bermudagrasses have been shown to be in close agreement (Anderson et al., 1988; Miller and Dickens, 1996). The response curve between test temperature and EL was fitted to a sigmoidal response using Sigmaplot (version 10; Systat Software, San Jose, CA). Response curves were developed for each treatment and each LT50 was determined from the inflection point of the curve based on the sigmoidal response equation (Anderson et al., 1988; Cardona et al., 1997; Zhang et al., 2006).

EXPERIMENTAL DESIGN AND DATA ANALYSIS. In each of the two experiments (cultivars under CA and ABA treatment), a randomized complete block design was used with four replications. The cultivars without CA were sampled for analysis of dehydrin expression only. The data were analyzed using an analysis of variance and mean separations were performed using a Fisher's protected least significant difference test. Correlations between LT50 and ABA level in each experiment were analyzed (SAS version 8e for Windows; SAS Institute, Cary, NC). Regression between LT50 and ABA level was also analyzed using Sigmaplot (version 10). Because the sample sizes for the freezing tests were small, no attempt was made to examine growth recovery from nodes after freezing.

\section{Results}

Cultivar differences in ABSCISIC ACID CONTENT. ABA content in leaves and stolons increased substantially during the first $7 \mathrm{~d}$ of CA and remained relatively stable thereafter (Fig. 1). Significant differences in ABA content were found among cultivars. When averaged over the four cultivars, leaf ABA content was increased by 3.2 -fold from day 0 through day 7 (Fig. 1A). 'Patriot' and 'Riviera' had greater leaf ABA content relative to 'Tifway' and 'Princess' when measured at $21 \mathrm{~d}$ of CA. Similar patterns were observed in stolon ABA content of the four cultivars (Fig. 1B). Stolon ABA content in 'Patriot', 'Riviera', 'Tifway', and 'Princess' was increased by 4.5 -fold, 3.5-fold, 2.9-fold, and 2.6-fold, respectively, from day 0 through day 7 of CA. When measured at $21 \mathrm{~d}$ of CA, stolon ABA content was $39.6 \mathrm{ng} \cdot \mathrm{g}^{-1}$ for 'Patriot', $35.1 \mathrm{ng} \cdot \mathrm{g}^{-1}$ for 'Riviera', $27.2 \mathrm{ng} \cdot \mathrm{g}^{-1}$ for 'Tifway', and $13.0 \mathrm{ng} \cdot \mathrm{g}^{-1}$ for 'Princess', respectively. 'Patriot' and 'Riviera' had greater ABA content in leaf and stolon tissues relative to 'Tifway' and 'Princess' during CA.

Cultivar Differences in DehYdRIN EXPRession. Dehydrin with a size of $40 \mathrm{kDa}$ was found in all cultivars, regardless of CA. Cold acclimation induced expression of a $25 \mathrm{kDa}$ dehydrin. 

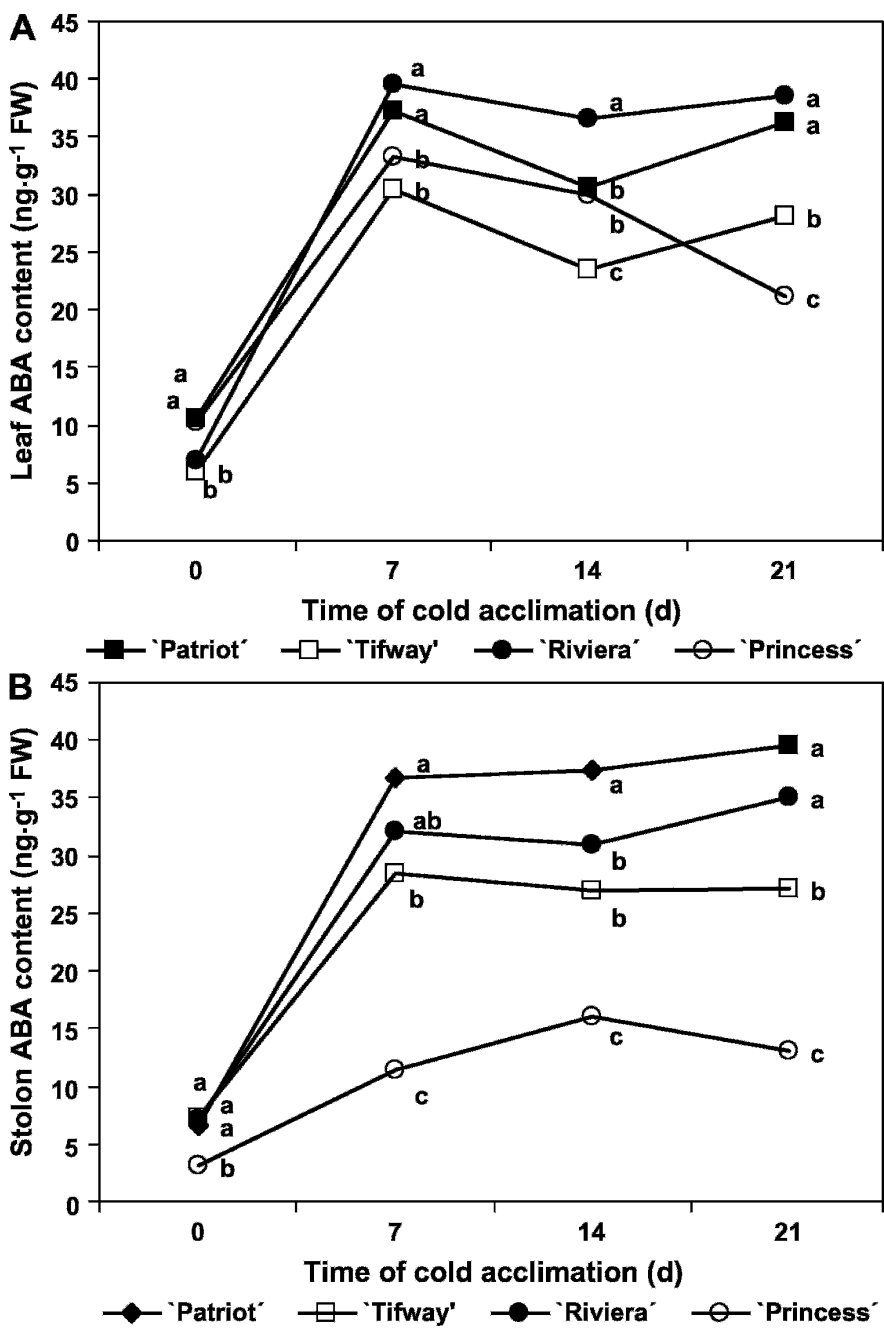

Fig. 1. Abscisic acid (ABA) content in (A) leaf and (B) stolon tissues of four bermudagrass cultivars (Patriot, Tifway, Riviera, and Princess) during cold acclimation $\left(8{ }^{\circ} \mathrm{C}\right.$ day $/ 4{ }^{\circ} \mathrm{C}$ night $)$; ABA values marked with same letters on each sampling date are not significantly different at $P \leq 0.05$.

However, there was no cultivar difference in abundance of this dehydrin (Fig. 2A).

EXOGENOUS ABSCISIC ACID IMPACTS ON DEHYDRIN EXPRESSION. Dehydrin with a size of $40 \mathrm{kDa}$ was found in all treatments. Applying $\mathrm{ABA}$ at various concentrations to nonacclimated 'Patriot' induced expression of a $25 \mathrm{kDa}$ dehydrin (Fig. 2B). The abundance of the $25 \mathrm{kDa}$ dehydrin was greater when the grass was treated with $\mathrm{ABA}$ at $50 \mu \mathrm{m}$ relative to $100 \mu \mathrm{M}$ and $150 \mu \mathrm{M}$.

Cultivar DifFERENCES IN ELECTROLYTE LEAKAGE AND LETHAL TEMPERATURE FOR 50\% LOSS OF ELECTROLYTES. Leaf EL increased during CA, especially from $14 \mathrm{~d}$ through $21 \mathrm{~d}$ of CA (Fig. 3). 'Patriot' and 'Riviera' had less EL relative to 'Tifway' when measured at 14 and $21 \mathrm{~d}$ of CA. 'Princess' had less EL relative to 'Tifway' at $21 \mathrm{~d}$ of CA.

Stolon EL increased as temperature decreased from -2 to $-10{ }^{\circ} \mathrm{C}$ (Fig. 4). 'Patriot' had less EL relative to 'Princess' at temperatures of $-4,-8$, and $-10^{\circ} \mathrm{C}$. 'Riviera' had less EL relative to 'Princess' at -6 and $-8{ }^{\circ} \mathrm{C}$. 'Patriot' had a lower average LT50 relative to 'Tifway' and 'Princess' (Fig. 5).

RELATIONSHIP BETWEEN LETHAL TEMPERATURE FOR 50\% LOSS OF ELECTROLYTES AND ABSCISIC ACID CONTENT. Linear regres-
A MW Marker Patriot Princess Tifway Riviera MW (kDa)

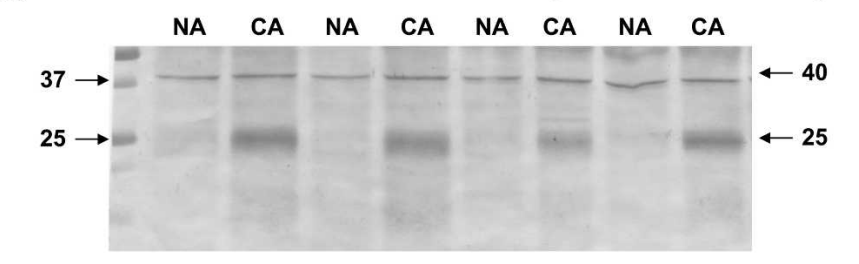

B MW Marker ABA ( $\mu \mathrm{M}) \quad$ MW (kDa)

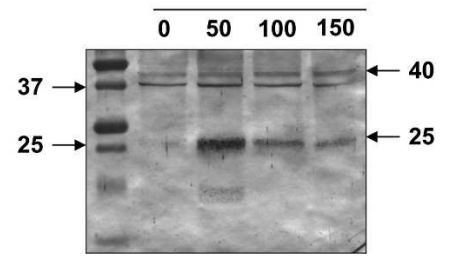

Fig. 2. Dehydrin expression in stolon tissues of four bermudagrass cultivars (Patriot, Tifway, Riviera, and Princess). Each of the cultivars was grown either under normal temperatures [not cold-acclimated (NA), $28^{\circ} \mathrm{C}$ day $/ 24^{\circ} \mathrm{C}$ night] or subjected to cold acclimation $\left(\mathrm{CA}, 8^{\circ} \mathrm{C}\right.$ day $/ 4^{\circ} \mathrm{C}$ night $)$ for $21 \mathrm{~d}(\mathbf{A})$. Dehydrin expression in stolon tissues in NA 'Patriot' bermudagrass treated with $\mathrm{ABA}$ at 0 (ABA0), $50 \mu \mathrm{M}$ (ABA50), $100 \mu \mathrm{M}$ (ABA100), and $150 \mu \mathrm{M}$ (ABA150) and grown under normal temperatures $\left(28^{\circ} \mathrm{C}\right.$ day $/ 24^{\circ} \mathrm{C}$ night $)$ for $21 \mathrm{~d}(\mathbf{B})$. Molecular weight (MW) markers represent dehydrins sized 25 and $37 \mathrm{kDa}$ (A and $\mathbf{B}$, far left).

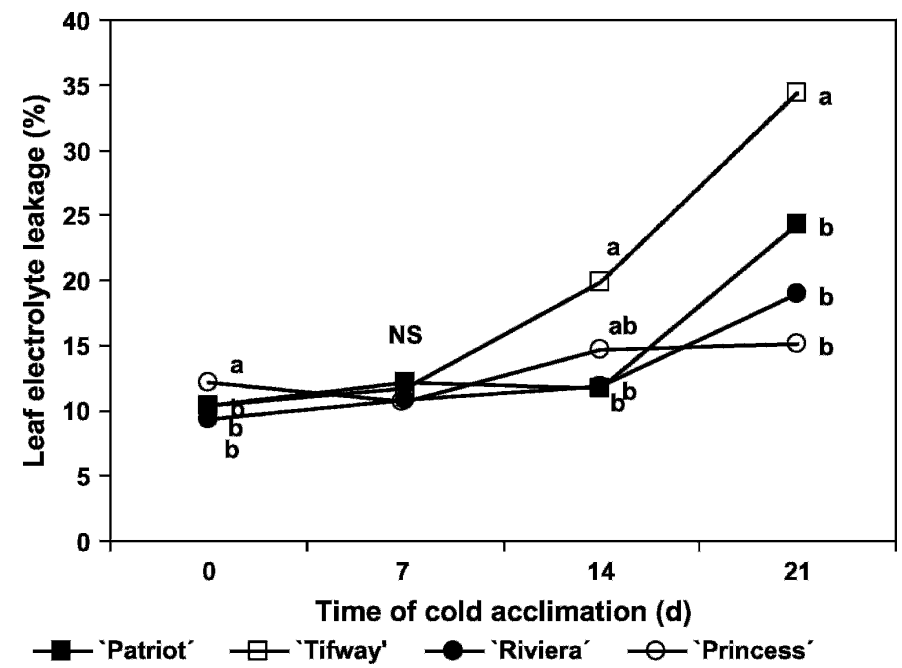

Fig. 3. Leaf electrolyte leakage (EL) of four bermudagrass cultivars (Patriot, Tifway, Riviera, and Princess) during cold acclimation $\left(8^{\circ} \mathrm{C}\right.$ day $/ 4{ }^{\circ} \mathrm{C}$ night). EL values marked with same letters on each sampling date are not significantly different at $P \leq 0.05$; NS = nonsignificant at the sampling date.

sions of leaf and stolon ABA content with LT50 were found (Fig. 6). Spearman correlation coefficients of LT50 with leaf $\left(\mathrm{r}=0.686^{* *}\right)$ and stolon $\left(\mathrm{r}=0.752^{* *}\right)$ ABA content were statistically significant at a $1 \%$ probability level.

EXOGENOUS ABSCISIC ACID IMPACTS ON ENDOGENOUS ABSCISIC ACID CONTENT. ABA treatment at $150 \mu \mathrm{M}$ consistently increased leaf and stolon ABA content in 'Patriot' bermudagrass (Fig. 7). Applying ABA at $100 \mu \mathrm{m}$ also increased stolon ABA content. $\mathrm{ABA}$ treatment at $50 \mu \mathrm{m}$ increased leaf and stolon $\mathrm{ABA}$ content when measured $21 \mathrm{~d}$ after application. Applying ABA at 50,100 , and $150 \mu \mathrm{M}$ increased stolon ABA content by 2.1fold, 2.4-fold, and 2.9-fold, respectively, when measured $21 \mathrm{~d}$ after treatment. 


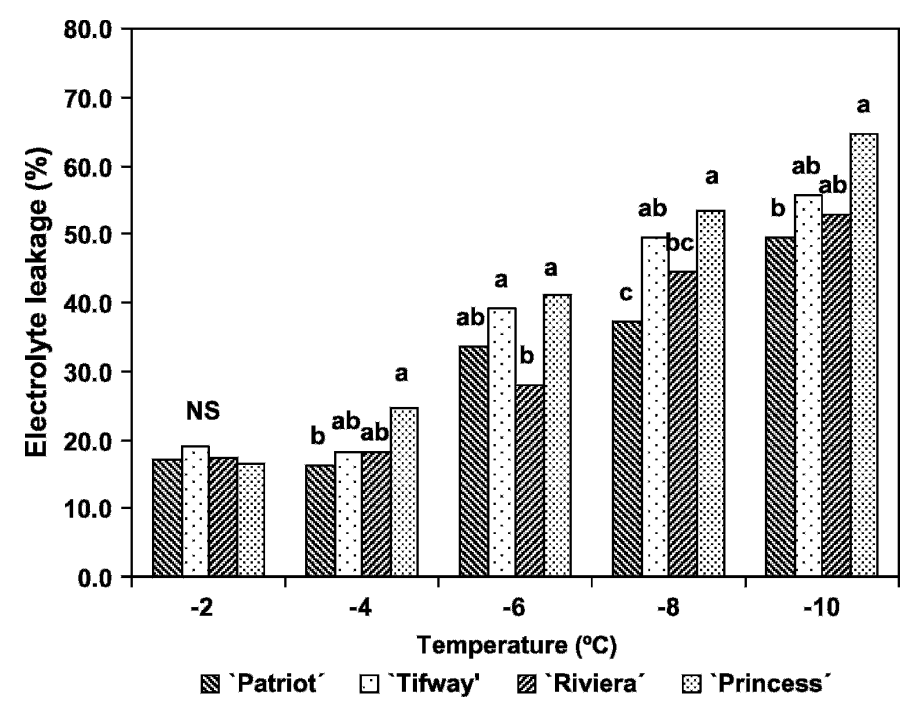

Fig. 4. Stolon electrolyte leakage (EL) of four bermudagrass cultivars (Patriot, Tifway, Riviera, and Princess) after $21 \mathrm{~d}$ of cold acclimation $\left(8^{\circ} \mathrm{C}\right.$ day $/ 4{ }^{\circ} \mathrm{C}$ night) and under freezing temperatures. EL values marked with same letters on each temperature are not significantly different at $P \leq 0.05$; NS $=$ nonsignificant at the specific temperature.

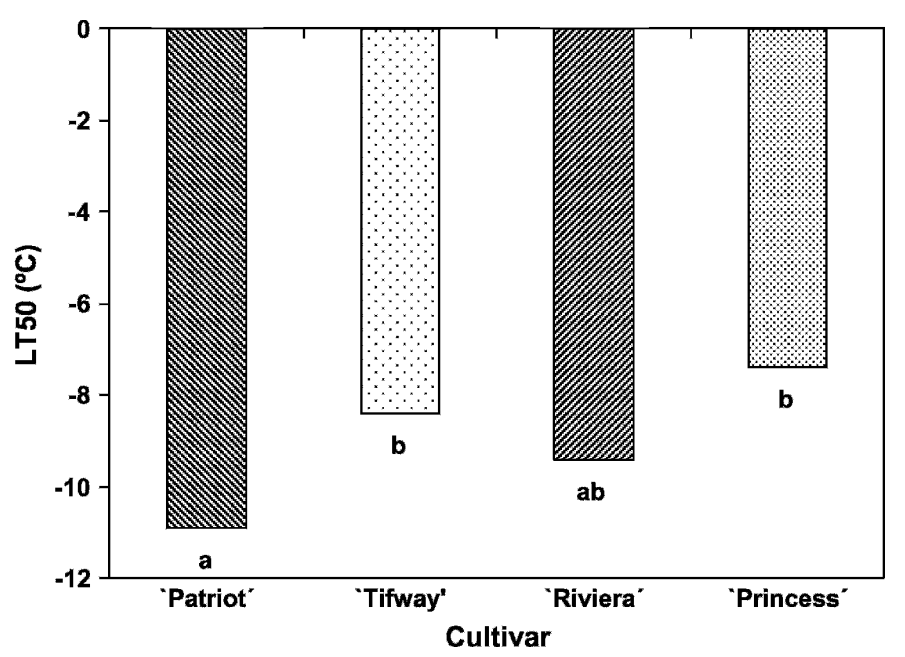

Fig. 5. Lethal temperature for $50 \%$ loss of electrolytes (LT50) of four bermudagrass cultivars (Patriot, Tifway, Riviera, and Princess) after $21 \mathrm{~d}$ of cold acclimation $\left(\mathrm{CA}, 8{ }^{\circ} \mathrm{C}\right.$ day $/ 4{ }^{\circ} \mathrm{C}$ night). LT50 values marked with same letters on each sampling date are not significantly different at $P \leq 0.05$.

EXOGENOUS ABSCISIC ACID IMPACTS ON ELECTROLYTE LEAKAGE AND LETHAL TEMPERATURE FOR 50\% LOSS OF ELECTROLYTES. Exogenous ABA at 100 and $150 \mu \mathrm{M}$ reduced leaf EL at $7 \mathrm{~d}$ after treatment (Fig. 8). Applying ABA at $100 \mu \mathrm{M}$ reduced stolon EL at temperatures of -4 and $-8{ }^{\circ} \mathrm{C}$. Exogenous $\mathrm{ABA}$ at $150 \mu \mathrm{M}$ also reduced stolon EL at -6 and $-10{ }^{\circ} \mathrm{C}$ (Fig. 9). All ABA treatments significantly improved freezing tolerance of 'Patriot' bermudagrass in terms of average LT50 values (Fig. 10).

Positive linear regression of stolon ABA content with LT50 was found (Fig. 11). Spearman correlation coefficients of LT50 with leaf $\left(\mathrm{r}=0.504^{*}\right)$ and stolon $\left(\mathrm{r}=0.812^{* *}\right)$ ABA content were statistically significant at $5 \%$ and $1 \%$ probability levels, respectively.
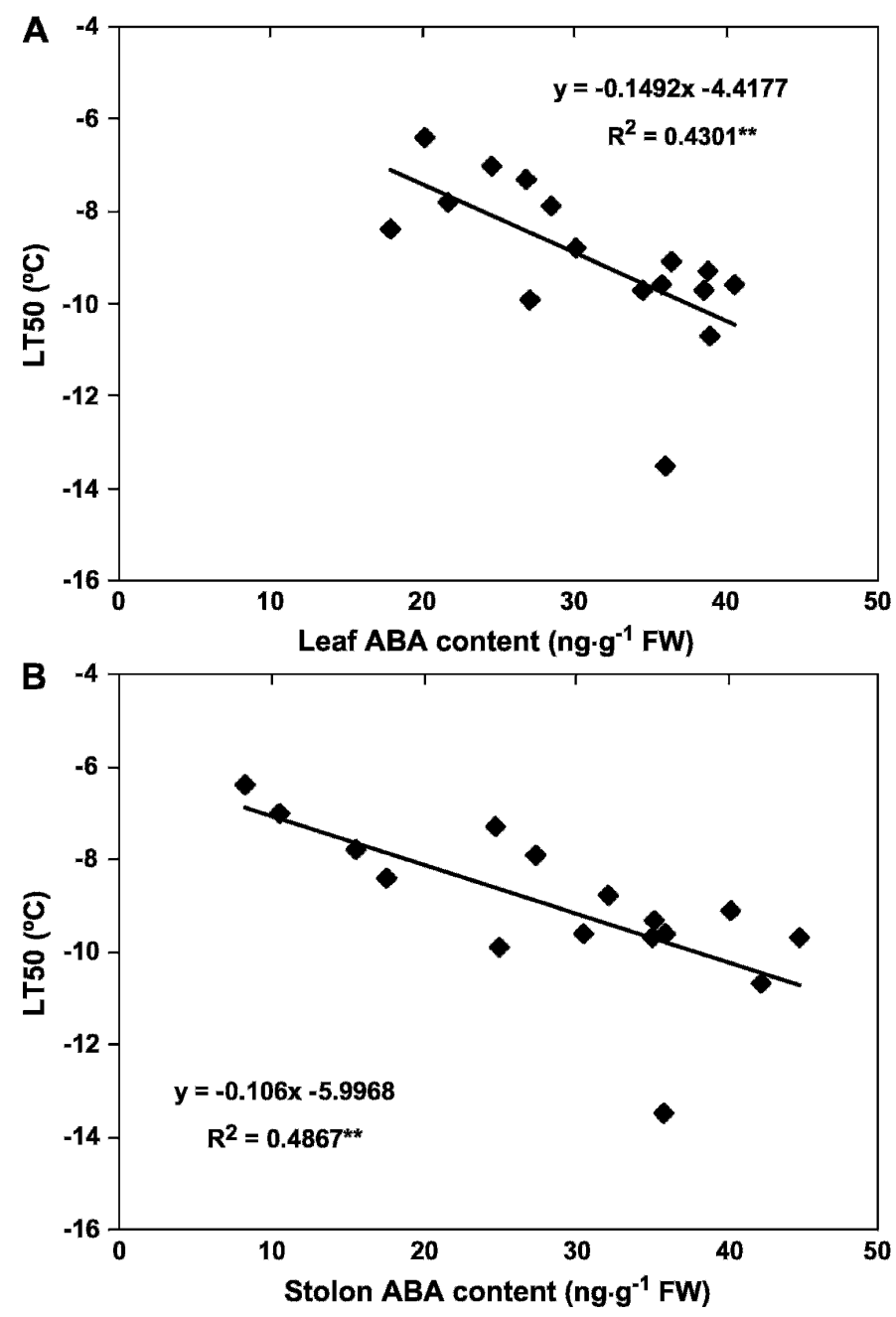

Fig. 6. Relationship of LT50 with abscisic acid (ABA) content in (A) leaf and (B) stolon tissues of four bermudagrass cultivars (Patriot, Tifway, Riviera, and Princess) after $21 \mathrm{~d}$ of cold acclimation $\left(8^{\circ} \mathrm{C}\right.$ day $/ 4{ }^{\circ} \mathrm{C}$ night $) ; * *$ significance of the linear regression at $P=0.01$.

\section{Discussion}

The results of this study indicated that ABA content in leaf and stolon tissues increased substantially during CA. 'Patriot' and 'Riviera' (cold-tolerant) had significantly greater ABA content when compared with 'Tifway' and 'Princess' (relatively cold-sensitive). A significant correlation was found between ABA content and LT50. The results are in agreement with previous studies with other plant species (Lee and Chen, 1993; Thomashow, 1999). Several lines of evidence suggest that ABA is involved in CA of plants (Thomashow, 1999). ABA content has been shown to increase transiently in both herbaceous and woody plants exposed to low temperature (Lee and Chen, 1993; Li et al., 1997). Exogenous application of $\mathrm{ABA}$ at nonstress temperatures leads to increased chilling and freezing tolerance (Chen and Gusta, 1983; Lang et al., 1989; Li et al., 2003; Thomashow, 1999), de novo protein synthesis, and induction of cold-responsive genes (De Los Reyes et al., 2001; Gatschet et al., 1996). In addition, both ABA-insensitive (abi) and ABA $(a b a)$-deficient mutants have been shown to have impaired CA (Gilmour and Thomashow, 1991; Heino et al., 

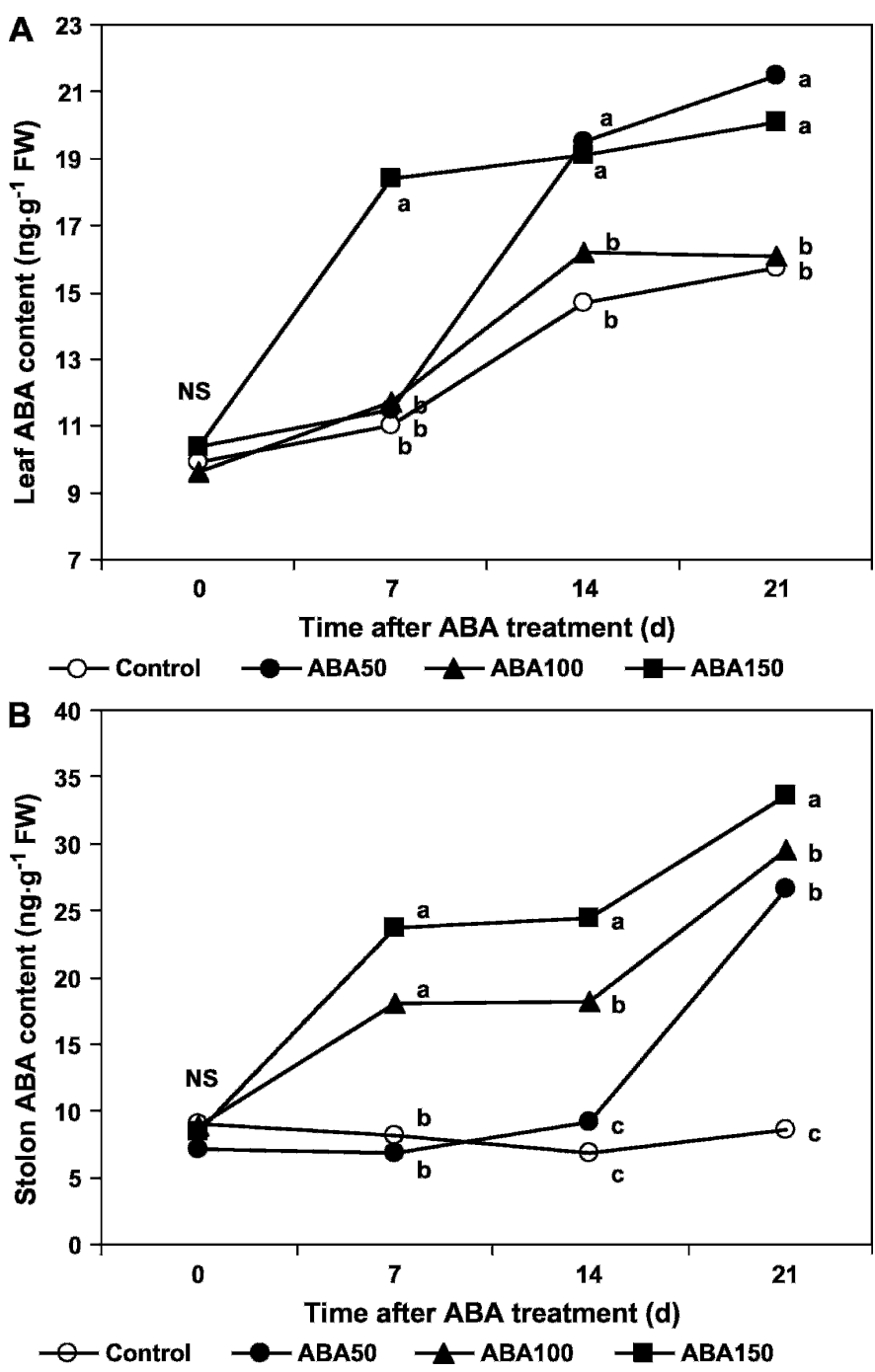

Fig. 7. Abscisic acid (ABA) content in (A) leaf and (B) stolon tissues of 'Patriot' bermudagrass grown under normal temperatures $\left(28{ }^{\circ} \mathrm{C}\right.$ day $/ 24{ }^{\circ} \mathrm{C}$ night $)$ as influenced by exogenous $\mathrm{ABA}$. The ABA was applied to the canopy at concentrations of 0 (Control), $50 \mu \mathrm{M}$ (ABA50), $100 \mu \mathrm{M}$ (ABA100), and $150 \mu_{\mathrm{M}}$ (ABA100). ABA values marked with same letters on each sampling date are not significantly different at $P \leq 0.05$; NS $=$ nonsignificant at the specific sampling date.

1990; Thomashow, 1999). Furthermore, it has been shown that application of ABA can suppress the impaired CA phenotype in the $a b a$ mutant (Heino et al., 1990; Thomashow, 1999). This suggests that changes in $\mathrm{ABA}$ metabolism during $\mathrm{CA}$ or in response to exogenous $\mathrm{ABA}$ may contribute to freezing tolerance improvement.

Cold acclimation induced expression of the $25 \mathrm{kDa}$ dehydrin, but no cultivar differences were found in terms of abundance of this dehydrin. Exogenous ABA induced expression of this dehydrin in 'Patriot' bermudagrass. This suggests that expression of the $25 \mathrm{kDa}$ dehydrin may be associated with CA or exogenous ABA treatment. Lim et al. (1999) first studied the role of dehydrins in rhododendron (Rhododendron L.) cold hardiness and found levels of a $25 \mathrm{kDa}$ dehydrin were closely associated with differences in leaf freezing tolerance. They suggest that this dehydrin could serve as a biochemical marker to distinguish between superhardy and less hardy rhododendron

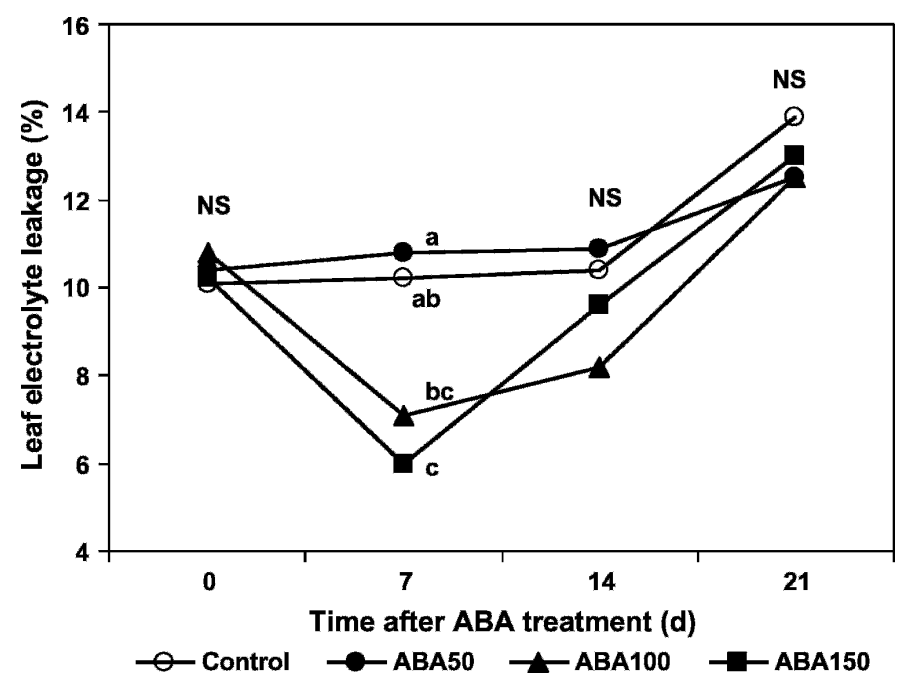

Fig. 8. Leaf electrolyte leakage (EL) of 'Patriot' bermudagrass grown under normal temperatures $\left(28^{\circ} \mathrm{C}\right.$ day $/ 24^{\circ} \mathrm{C}$ day/night) as influenced by exogenous abscisic acid (ABA). The ABA was applied to the canopy at concentrations of 0 (Control), $50 \mu \mathrm{M}$ (ABA50), $100 \mu \mathrm{M}$ (ABA100), and $150 \mu \mathrm{M}$ (ABA100). EL values marked with same letters on each sampling date are not significantly different at $P \leq 0.05 ; \mathrm{NS}=$ nonsignificant at the specific sampling dates.

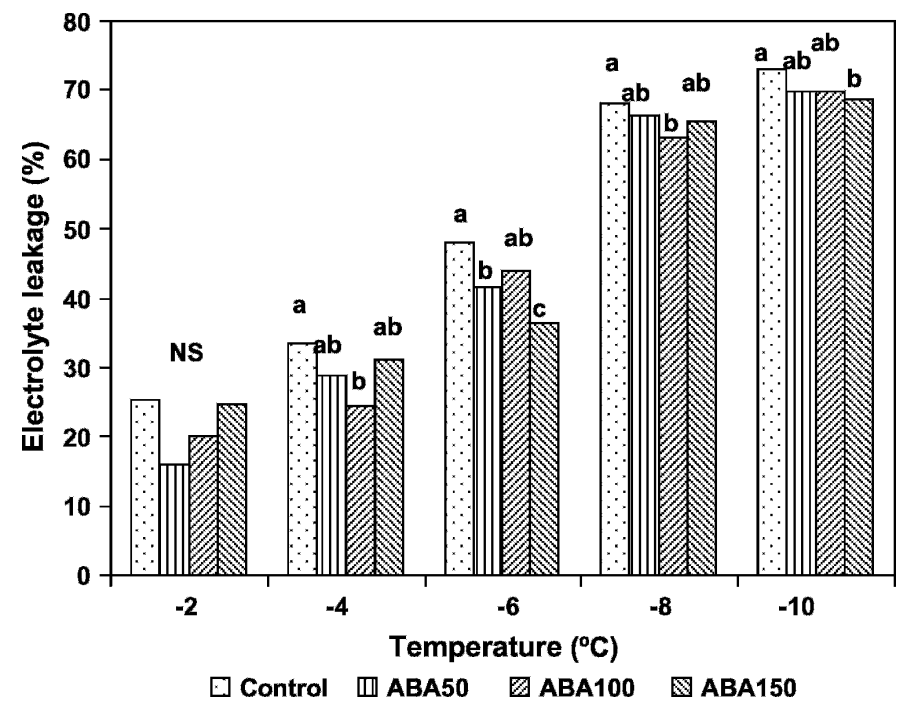

Fig. 9. Stolon electrolyte leakage (EL) of 'Patriot' bermudagrass under normal temperatures $\left(28^{\circ} \mathrm{C}\right.$ day $/ 24^{\circ} \mathrm{C}$ night $)$ as influenced by exogenous abscisic acid (ABA). The ABA was applied to the canopy at concentrations of 0 (Control), $50 \mu \mathrm{M}$ (ABA50), $100 \mu \mathrm{M}$ (ABA100), and $150 \mu \mathrm{M}$ (ABA100). EL values marked with same letters on each sampling date are not significantly different at $P \leq 0.05$; NS $=$ nonsignificant at the specific temperature.

genotypes. Marian et al. (2003) examined the accumulation pattern of dehydrins in non- versus cold-acclimated leaves of 21 species comprising two divergent groups of rhododendron and found a close association $\left(\mathrm{R}^{2}=0.95\right)$ between relative changes in leaf freezing tolerance and $25 \mathrm{kDa}$ dehydrin accumulation. Patton et al. (2007) reported that dehydrin polypeptides (23 and $25 \mathrm{kDa}$ ) increased during $\mathrm{CA}$ and abundance of the $23 \mathrm{kDa}$ dehydrin polypeptide was positively associated with genetic variation in zoysiagrass freezing tolerance, but the $25 \mathrm{kDa}$ dehydrin was not. The results of this study suggest that exogenous ABA or CA may induce 


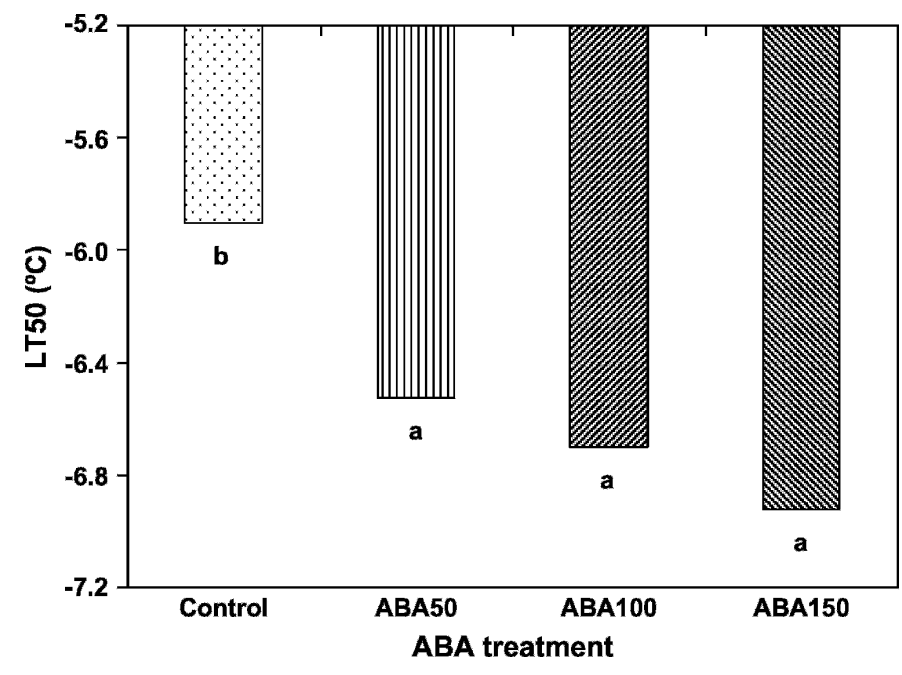

Fig. 10. Lethal temperature for $50 \%$ loss of electrolytes (LT50) of 'Patriot' bermudagrass grown under normal temperatures $\left(28{ }^{\circ} \mathrm{C}\right.$ day $/ 24{ }^{\circ} \mathrm{C}$ night $)$ as influenced by exogenous abscisic acid (ABA). The ABA was applied to the canopy at concentrations of 0 (Control), $50 \mu \mathrm{M}$ (ABA50), $100 \mu \mathrm{M}$ (ABA100), and $150 \mu \mathrm{M}$ (ABA100). LT50 values marked with same letters on each sampling date are not significantly different at $P \leq 0.05$.

expression of the $25 \mathrm{kDa}$ dehydrin in bermudagrass, and this dehydrin may contribute to freezing tolerance in bermudagrass but may not be a major factor causing the cultivar differences in freezing tolerance. Exogenous ABA or CA may induce other defense mechanisms [such as increases in expression of many cold-regulated genes (including other dehydrins), endogenous ABA, cellular pools of carbohydrates and animo acids, antioxidant activity, and so on], thus improving freezing tolerance (Kalberer et al., 2006; Thomashow, 1999; Zhang et al., 2006; Zhang and Ervin, 2008).

The results of our study indicated that exogenous $\mathrm{ABA}$ promoted endogenous ABA content in leaf and stolon tissues and dehydrin expression in stolon tissues and increased freezing tolerance in nonacclimated 'Patriot' bermudagrass. Stolon ABA content was positively correlated to freezing tolerance. The $25 \mathrm{kDa}$ dehydrin in stolon tissues of 'Patriot' was induced by either $\mathrm{CA}$ or ABA treatment. To our knowledge, this is the first report on effects of CA and exogenous $\mathrm{ABA}$ on endogenous $\mathrm{ABA}$ and dehydrin expression associated with freezing tolerance in selected bermudagrass cultivars differing in freezing tolerance. It has been documented that plant freezing tolerance is associated with ABA (Lee and Chen, 1993; Thomashow, 1999) and certain dehydrins (Danyluk et al., 1998; Marian et al., 2003; Patton et al., 2007). These studies, however, addressed either ABA or dehydrins only. The results of our study indicated that both $\mathrm{ABA}$ and the $25 \mathrm{kDa}$ dehydrin may be induced by $\mathrm{CA}$ or exogenous ABA, but ABA may be more closely associated with freezing tolerance of the bermudagrass cultivars relative to the $25 \mathrm{kDa}$ dehydrin. In seedlings of alfalfa (Medicago L.), tolerance to freezing at $-10{ }^{\circ} \mathrm{C}$ was greatly improved by previous cold exposure $\left(4^{\circ} \mathrm{C}\right)$ or by treatment with exogenous ABA without cold exposure. These treatments caused changes in the pattern of newly synthesized proteins. Some of the newly synthesized proteins induced by cold appear to be the same as those induced by ABA (Taiz and Zeiger, 2006). The results of this study suggest that applying $\mathrm{ABA}$ to 'Patriot' bermudagrass may mimic $\mathrm{CA}$ in inducing
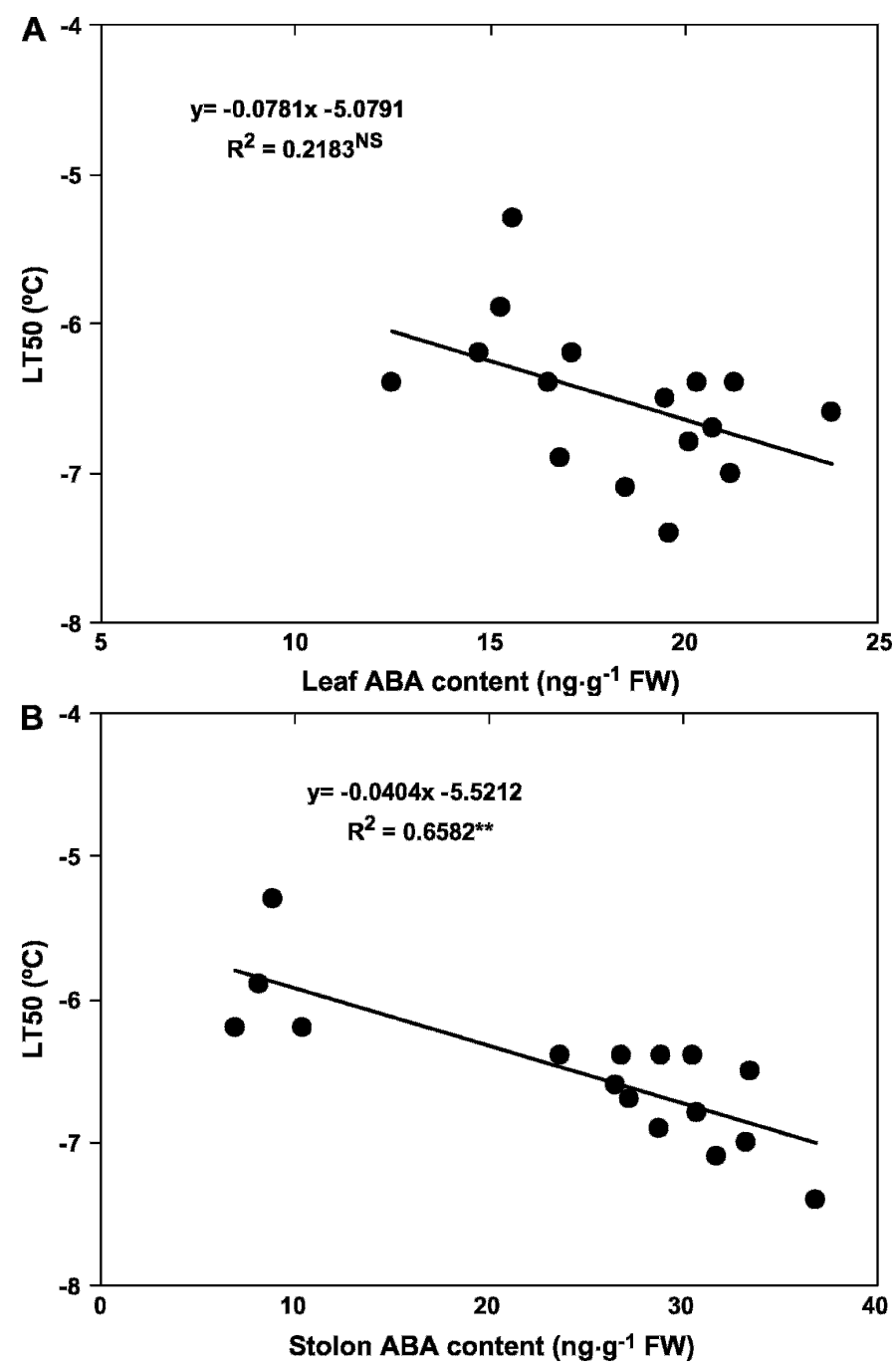

Fig. 11. Relationship of LT50 with abscisic acid (ABA) content in (A) leaf and (B) stolon tissues of exogenous ABA-treated 'Patriot' bermudagrass grown under normal temperatures $\left(28{ }^{\circ} \mathrm{C}\right.$ day $/ 24^{\circ} \mathrm{C}$ night $) ; * *$ significance of the linear regression at $P=0.01, \mathrm{NS}=$ nonsignificant at $P=0.05$.

plant defense responses and improving freezing tolerance. The complete underlying mechanisms of improved freezing tolerance remain unclear. There is evidence showing that exogenous ABA may signal initiation of a metabolic transition, increasing metabolic defenses and freezing tolerance (Thomashow, 1999). Exogenous ABA may trigger an accumulation of signaling molecules [such as reactive oxygen species (ROS), endogenous ABA; Xiong et al., 2002]. These molecules may signal plant defense responses such as an increase in expression of coldregulated genes (including dehydrins), antioxidants, nonstructural carbohydrates, and amino acids and alteration of cell membrane composition (De Los Reyes et al., 2001; Kalberer et al., 2006; Thomashow, 1999; Xiong et al., 2002; Zhang and Ervin, 2008; Zhou et al., 2005).

The results of this study indicated that leaf EL increased during CA. This suggests that CA may cause mild injury to cell membrane and an increase in EL possibly resulting from ROS accumulation in leaf tissues. The ROS may signal initiation of plant metabolic defense responses (such as increase in ABA, dehydrins, and antioxidants), which may improve integrity of 
cell membrane and reduce EL and LT50 (Zhang and Ervin, 2008). During CA, cold-tolerant cultivars may develop greater defense responses to suppress ROS toxicity and have lower EL and LT50 when compared with cold-sensitive cultivars. The cultivars' difference in EL and LT50 may be associated with their genetic background and capacity of metabolic defense responses (such as ABA, dehydrins, antioixdants, membrane lipids, and fatty acid constituents) during CA (Cyril et al., 2002; Zhang and Ervin, 2008). Our results showed that exogenous ABA reduced EL and LT50 of nonacclimated 'Patriot'. It is possible that exogenous ABA may induce plant metabolic defense responses directly and indirectly (through ROS) and improve integrity of cell membrane and freezing tolerance.

In summary, rapid increase in ABA content in leaf and stolon tissues during CA was positively associated with freezing tolerance. Bermudagrass cultivars with more ABA accumulation during $\mathrm{CA}$ may have better tolerance to freezing stress when compared with those with less ABA accumulation. ABA may be an important component in the signaling network for inducing freezing tolerance. Cold acclimation may induce expression of certain dehydrins such as the $25 \mathrm{kDa}$ dehydrin. Exogenous ABA at proper dosages (50 to $150 \mu \mathrm{M})$ may induce endogenous $\mathrm{ABA}$ and other defense responses similar to those occurring during $\mathrm{CA}$, improving bermudagrass freezing tolerance. Selection and use of cultivars with rapid accumulation of $\mathrm{ABA}$ and certain dehydrins during $\mathrm{CA}$ or in response to exogenous ABA could improve bermudagrass persistence in transition zone climates.

\section{Literature Cited}

Anderson, J.A., M.P. Kenna, and C.M. Taliaferro. 1988. Cold hardiness of 'Midiron' and 'Tifgreen' bermudagrass. HortScience 23:748-750.

Anderson, J.A., C.M. Taliaferro, and D.L. Martin. 1993. Evaluating freeze tolerance of bermudagrass in a controlled environment. HortScience 28:955-959.

Anderson, J.A., C.M. Taliaferro, and D.L. Martin. 2002. Freezing tolerance of bermudagrass: Vegetatively propagated cultivars intended for fairway and putting green use, and seed-propagated cultivars. Crop Sci. 42:975-977.

Anderson, J.A., C.M. Taliaferro, and D.L. Martin. 2003. Longer exposure durations increase freeze damage to bermudagrasses. Crop Sci. 43:973-977.

Anderson, M.P., C.M. Taliaferro, and J.A. Anderson. 1997. The cold facts on bermudagrass. Golf Course Mgt. 65:59-63.

Cardona, C.A., R.R. Duncan, and O. Lindstrom. 1997. Low temperature tolerance assessment in Paspalum. Crop Sci. 37:1283-1291.

Chen, T.H.H. and L.V. Gusta. 1983. Abscisic acid-induced freezing resistance in cultured plant cells. Plant Physiol. 73:71-75.

Close, T.J. 1997. Dehydrins: A commonalty in the response of plants to dehydration and low temperature. Physiol. Plant. 100:291-296.

Cyril, J., G.L. Powell, R.R. Duncan, and W.V. Baird. 2002. Changes in polar lipid fatty acids of seashore Paspallum in response to low temperature exposure. Crop Sci. 42:2031-2037.

Danyluk, J., A. Perron, M. Houde, A. Limin, B. Fowler, N. Benhamou, and F. Sarhan. 1998. Accumulation of an acidic dehydrin in the vicinity of the plasma membrane during cold acclimation of wheat. Plant Cell 10:623-638.

De Los Reyes, B.G., C.M. Taliaferro, and M.P. Anderson. 2001. Induced expression of the class II chitinase gene during cold acclimation and dehydration of bermudagrass (Cynodon sp.). Theor. Appl. Genet. 103:297-306.

Fry, J.D. 1990. Cold temperature tolerance of bermudagrass. Golf Course Mgt. 58:26, 28, 32.
Fry, J.D., N.S. Lang, and R.G.P. Clifton. 1991. Freezing resistance and carbohydrate composition of 'Floratam' st. augustinegrass. HortScience 26:1537-1539.

Fry, J.D., N.S. Lang, R.G.P. Clifton, and F.P. Maier. 1993. Freezing tolerance and carbohydrate content of low temperature-acclimated and non-acclimated centipedegrass. Crop Sci. 33:1051-1055.

Gatschet, M.J., C.M. Taliaferro, D.R. Porter, M.P. Anderson, J.A. Anderson, and K.W. Jackson. 1996. A cold-regulated protein from bermudagrass crowns is a chitinase. Crop Sci. 36:712-718.

Gilmour, S.J. and M.F. Thomashow. 1991. Cold acclimation and coldregulated gene expression in ABA mutants of Arabidopsis thaliana. Plant Mol. Biol. 17:1233-1240.

Han, B. and A.R. Kermode. 1996. Dehydrin-like proteins in castor bean seeds and seedlings are differentially produced in responses to ABA and water-deficit-related stresses. J. Expt. Bot. 47:933939.

Hara, M., T.F. Terashima, T. Fukaya, and T. Kuboi. 2003. Enhancement of cold tolerance and inhibition of lipid peroxidation by citrus dehydrin in transgenic tobacco. Planta 217:290-298.

Harlan, J.R. and J.M.J. de Wet. 1969. Sources of variation in Cynodon dactylon (L.). Pers. Crop Sci. 9:774-778.

Heino, P., G. Sandman, V. Lang, K. Nordin, and E.T. Palva. 1990. Abscisic acid deficiency prevents development of freezing tolerance in Arabidopsis thaliana (L.). Heynh. Theor. Appl. Genet. 79:801806.

Hiscock, E. 1996. Winterkill...the horror continues. Golf Course Mgt. 64:42, 44, 48.

Hughes, M.A. and M.A. Dunn. 1996. The molecular biology of plant acclimation to low temperature. J. Expt. Bot. 47:291-305.

Kalberer, S.R., M. Wisniewski, and R. Arora. 2006. Deacclimation and reacclimation of cold-hardy plants: Current understanding and emerging concepts. Plant Sci. 171:3-16.

Karpinski, S., G. Wingsle, B. Karpinska, and J. Hallgren. 2002. Lowtemperature stress and antioxidant defense mechanisms in higher plants, p. 69-104. In: Inze, D. and M.V. Montagu (eds.). Oxidative stress in plants. Taylor and Francis, London, UK.

Laemmli, U.K. 1970. Cleavage of structural proteins during the assembly of the head of bacteriophageT4. Nature 227:680-685.

Lang, V., P. Heino, and E.T. Palva. 1989. Low-temperature acclimation and treatment with exogenous abscisic acid induce common polypeptides in Arabidopsis thaliana (L.). Heynh. Theor. Appl. Genet. 77:729-734.

Lee, S.P. and T.H.H. Chen. 1993. Molecular biology of plant cold hardiness development, p. 1-30. In: Li, P.H. and L. Christersson (eds.). Advances in plant cold hardiness. CRC Press, Boca Raton, FL. Li, C., O. Junttila, P. Heino, and E.T. Palva. 2003. Different responses of northern and southern ecotypes of Betula pendula to exogenous ABA application. Tree Physiol. 23:481-487.

Li, P.H., W.P. Chen, L. Jian, and Z. Xin. 1997. Abscisic acid-induced chilling tolerance in maize, p. 215-224. In: Li, P.H. and T.H.H. Chen (eds.). Plant cold hardiness, molecular biology, biochemistry, and physiology. Plenum Press, New York, NY.

Lim, C.C., S.L. Krebs, and R. Arora. 1999. A 25-kDa dehydrin associated with genotype- and age-dependent leaf freezing tolerance in rhododendron: A genetic marker for cold hardiness? Theor. Appl. Genet. 99:912-928.

Marian, C.O., S.L. Krebs, and R. Arora. 2003. Dehydrin variability among rhododendron species: A $25-\mathrm{kDa}$ dehydrin is conserved and associated with cold acclimation across diverse species. New Phytol. 161:773-780.

McCarty, L.B. and G. Miller. 2002. Managing bermudagrass turf: Selection, construction, cultural practices, and pest management strategies. Ann Arbor Press, Chelsea, MI.

Miller, G.L. and R. Dickens. 1996. Potassium fertilization related to cold resistance in bermudagrass. Crop Sci. 36:1290-1295.

Munshaw, G.C. 2004. Nutritional and PGR effects on lipid unsaturation, osmoregulant content, and relation to bermudagrass cold hardiness. Virginia Tech, Blacksburg, VA PhD Diss. 
Munshaw, G.C., E.H. Ervin, C. Shang, S.D. Askew, X. Zhang, and R.W. Lemus. 2006. Influence of late-season iron, nitrogen, and seaweed extract on fall color retention and cold tolerance of four bermudagrass cultivars. Crop Sci. 46:273-283.

National Turfgrass Evaluation Program. 2008. Percent winterkill ratings of bermudagrass cultivars, 2003-06. 10 Jan. 2008. $<$ http://www.ntep.org/reports/bg02/bg02_07-10f/bg02_0710f.htm>.

Nylander, M., J. Svensson, E.T. Palva, and B.V. Welin. 2001. Stress-induced accumulation and tissue-specific localization of dehydrins in Arabidopsis thaliana. Plant Mol. Biol. 45:263279.

Patton, A.J., S.M. Cunningham, J.J. Volenec, and Z.J. Reicher. 2007. Differences in freeze tolerance of zoysiagrass: I. Role of proteins. Crop Sci. 47:2162-2169.

Perras, M. and F. Sarhan. 1989. Synthesis of freezing tolerance proteins in leaves, crown, and roots during cold acclimation of wheat. Plant Physiol. 89:577-585.

Shashikumar, K. and J.L. Nus. 1993. Cultivar and winter cover effects on bermudagrass cold acclimation and crown moisture content. Crop Sci. 33:813-817.

Taiz, L. and E. Zeiger. 2006. Plant physiology. 4th Ed. Benjiamin and Cummings, San Francisco, CA.

Taliaferro, C.M., D.L. Martin, J.A. Anderson, M.P. Anderson, and A.C. Guenzi. 2004. Broadening the horizons of turf bermudagrass. U.S. Golf Assn. Turfgrass Environ. Res. Online 3:1-9. 10 Jan. 2008. $<$ http://www.usgatero.msu.edu/v03/n20.pdf $>$.
Thomashow, M.F. 1999. Plant cold acclimation: Freezing tolerance genes and regulatory mechanisms. Annu. Rev. Plant Physiol. Plant Mol. Biol. 50:571-599.

Walker-Simmons, M.K., P.A. Rose, L.R. Hogge, and S.R. Abrams. 2000. Abscisic acid: ABA immunoassay and gas chromatography/ mass spectrometry verification, p. 33-48. In: Tucker, G.A. and J.A. Roberts (eds.). Plant hormone protocols, methods in molecular biology. Vol. 141. Humana Press, Totowa, NJ.

Wisniewski, M., R. Webb, R. Balsamo, T.J. Close, X.M. Yu, and M. Griffith. 1999. Purification, immunolocalization, cryoprotective, and antifreeze activity of PCA60: A dehydrin from peach (Prunus persica). Physiol. Plant. 105:600-608.

Xiong, L., K.S. Schumaker, and J.K. Zhu. 2002. Cell signaling during cold, drought, and salt stress. Plant Cell 14:S165-S183.

Zhang, X. and E.H. Ervin. 2008. Metabolic defense responses of bermudagrass during acclimation to freezing stress-A review. Acta Hort. 783:181-194.

Zhang, X., E.H. Ervin, and A.J. LaBranche. 2006. Metabolic defense responses of seeded bermudagrass during acclimation to freezing stress. Crop Sci. 46:2598-2605.

Zhou, B., Z. Guo, and Z. Liu. 2005. Effects of abscisic acid on antioxidant systems of Stylosanthes guianensis (Aublet) Sw. under chilling stress. Crop Sci. 45:599-605.

Zhu, B., D.W. Choi, R. Fenton, and T.J. Close. 2000. Expression of the barley dehydrin multigene family and the development of freezing tolerance. Mol. Gen. Genet. 264:145-153. 